\title{
Physicochemical and Microbiological Analysis of Drinking Water in Al Kamleen City, Gezira State
}

\author{
Tahani H., Al Agib ${ }^{1}$, Elnasri M. Mututali ${ }^{2}$ \\ ${ }^{1,2}$ Department of Biology, Faculty of Education \\ Alzaiem Alazhari University, Sudan
}

\begin{abstract}
The study was carried out in Al Kamleen City in Gezira State in central Sudan, to evaluate the drinking water quality by looking into physicochemical and micro-biological aspects. Ten samples of water were collected randomly from different sites in the city and examined for electrical conductivity (E.C.), turbidity, pH and total dissolved solids (TDS). The samples were also examined for the presence of microorganisms during winter, summer and autumn. Results showed that most of the parameters examined were within the limit of the Sudanese standards and Metrology Organization (SSMO, 2015) and the World Health Organization (WHO, 2007). Some samples were contaminated by bacteria including coliform, Escherichia coli and salmonellas and the higher contamination was in autumn.
\end{abstract}

Keywords:- Drinking water, Physicochemical analysis, Micro-biological analysis, Al Kamleen City.

\section{INTRODUCTION}

Good drinking water quality is essential for the wellbeing of all people. Safe water is a pre-condition for health and development and a basic human right, yet it is still denied to hundreds of millions of people throughout the developing world. Water related diseases caused by insufficient safe water supplies coupled with poor sanitation and hygiene cause many deaths a year, mostly among children. Fecal coliforms have been seen as an indicator of fecal contamination and commonly used to express microbiological quality of water and as a parameter to estimate disease risk (WHO, 1993).

Water used in Sudan derives almost from surface water resources, as ground water is used only in limited areas. As in many countries around the world, including Sudan, some drinking water supplies have become contaminated, which has impacted on the health of population.

Al Kamleen is a city located near the Blue Nile River in Central Sudan, in Gezira State. The supply of drinking water was from the Nile. The present study was undertaken to assess the water quality by determining the physicochemical and microbiological analysis of water samples.

\section{MATERIALS AND METHDS}

\section{Sampling:}

Water samples from Al Kamleen City were collected from 10 sites selected randomly. The samples were taken in winter, summer and autumn. The samples were collected during the day in sterile screw-cap bottles and examined in the laboratory immediately after arrival.

\section{> Physicochemical examination:}

The water samples were examined to determine electrical conductivity (E.C), using a Hatch multimeter, turbidity using turbidometer, the $\mathrm{pH}$ measured the $\mathrm{pH}$ meter Meodel 3516. The total dissolved solids (TDS) were analyzed using methods prescribed by APHA (1998).

\section{Microbiological examination:}

The samples were undertaken to examine the total viable bacterial count which was carried out using the pour plate technique according to Harrigan (1998). The most probable number (MPN) and salmonella test were carried out according to methods prescribed by APHA, AWWA and WPCF (1998) and WHO (2004).

\section{RESULTS AND DISCUSSION}

\section{$>$ Physicochemical parameters}

Table (1) showed the electrical conductivity (E.C.) with the highest value $0.740 \mathrm{ds} / \mathrm{m}$ in sample number 5 and the lower value $0.243 \mathrm{ds} / \mathrm{m}$ in sample number 10 . All the values of E.C. fall within the Sudanese Standards and Metrology Organization (SSMO, 2015) and International Standards of WHO (2007). Similar observations were reported by Ali (2008) who found that the E.C. ranged from 233-1754 $\mu \mathrm{s} / \mathrm{cm}$ in Khartoum State. Also Khojaly (2011) reported that the E.C. of the samples ranged from 305-1356 $\mu \mathrm{s} / \mathrm{cm}$ in Khartoum State.

The highest turbidity (9.10 NTU) was recorded in sample No. 10; this value exceeded the Sudanese standards limit (5NTU) and the WHO (2007) limited. The other samples values ranged from 1.00 to $1.4 \mathrm{NTU}$, these values were within the limit of SSMO (2015) and WHO (2007). The highest value of turbidity was in sample No. 10 which was taken directly from Blue Nile River and as it was known this river receives large volume of storm water with suspended materials, which consequently increased the turbidity of the water. Similar results were reported by Elbakry (2009) who found that turbidity level ranged from 
0.30 to $0.95 \mathrm{NTU}$ in groundwater and from 5.5 to $19 \mathrm{NTU}$ in surface water. Alkhiry (2016) found the range of turbidity from 0.01 to 6 NTU in Khartoum City.

The consumption of highly turbid water may constitute a health risk as excessive turbidity water may constitute a health risk as excessive turbidity can interfere with disinfection and provide a medium for microbial growth.

As shown in Table (1) the highest $\mathrm{pH}$ value 8.40 was recorded in sample number 5 and the lowest one 7.49 was found sample number 3 . All values of the $\mathrm{pH}$ were within the permissible limited of the SSMO (2015) and WHO (2007). Similar results were reported by Abdel Halim (2010) who found the $\mathrm{pH}$ value in ground water between 7.63 and 8.02. Alkhiry (2016) found the $\mathrm{pH}$ of water samples taken from Khartoum city ranged from 7 to 7.9 . The pH usually has no direct impact on consumers, but it is one of the most important operational water palatability of water, but corrosive effect on distribution system is more urgent problem (IEPA, 2001).

\begin{tabular}{|c|c|c|c|c|}
\hline Sample No. & $\begin{array}{c}\text { EC } \\
(\mathrm{ds} / \mathrm{m})\end{array}$ & $\begin{array}{c}\text { Turbidity } \\
(\mathrm{NTU})\end{array}$ & $\mathrm{pH}$ & $\begin{array}{c}\text { TDS } \\
(\mathrm{mg} / \mathrm{L})\end{array}$ \\
\hline 1 & 0.709 & 1.25 & 8.00 & 453.76 \\
\hline 2 & 0.705 & 1.30 & 7.74 & 451.20 \\
\hline 3 & 0.675 & 1.00 & 7.49 & 432.00 \\
\hline 4 & 0.714 & 1.08 & 7.95 & 456.96 \\
\hline 5 & 0.740 & 1.36 & 8.40 & 473.60 \\
\hline 6 & 0.685 & 1.35 & 7.67 & 438.40 \\
\hline 7 & 0.576 & 1.00 & 7.54 & 368.64 \\
\hline 8 & 0.694 & 1.40 & 7.67 & 447.36 \\
\hline 10 & 0.284 & 1.10 & 8.00 & 381.76 \\
\hline
\end{tabular}

Table 1:- Physicochemical quality of water samples taken from Al Kamleen city, Gezira State

The highest value of total dissolved solids (TDS) $473 \mathrm{mg} / \mathrm{Lwas}$ found in sample number 5 and the lowest value $368.64 \mathrm{mg} / \mathrm{L}$ was recorded by sample number 7 . All these values were within the range of WHO (2007) and SSMO (2015). In connection to this, Ali (2008) observed that the TDS values ranged from 133.7 to $1548 \mathrm{mg} / \mathrm{L}$ in Khartoum State. Alkhiry (2016) found the TDS ranged from 135 to $460 \mathrm{mg} / \mathrm{L}$ in Khartoum city. An elevated water TDS may be associated with an elevated water hardness, chemical deposits, corrosion by-products, staining or salty bitter tastes (WHO, 2006).

\section{> Microbiological parameters:}

In Table (2) the least viable count of bacteria in winter was found in sample number 4 and the highest value was found in sample number 10, this result was expected as this sample was taken from the Blue Nile River directly (untreated water). Table (2) also indicated the presence of coliform and Escherichia coli and the presence of salmonella in $30 \%$ of the samples. These results indicated that these samples were contaminated and unfit for human use according to the Sudanese Standards and Metrology Organiza-tion (SSMO, 2015) and the International Standards (WHO, 2004).
In summer season the total viable count of bacteria was higher than in winter season and the percentage of total coliform and E. coli was 50 and $30 \%$ respectively. The salmonella was also detected in $30 \%$ of the totals samples. This means that some of the water samples were contaminated and did not fulfill the Sudanese Standards (SSMO, 2015) and WHO (2004). On the other hand, the highest total viable count of bacteria was recorded in autumn. In this season the highest total coliform 87 and the highest E. coli 41 as recorded, representing 90 and $70 \%$ of the total samples respectively. These results indicated that $90 \%$ of the samples were unfit for drinking according to the Sudanese Standards (SSMO, 2015) and the International Standards (WHO, 2004) for drinking water, which stated that $E$. coli or thermotolerant coliform bacteria must not be detectable in any $100 \mathrm{ml}$ sample. Similar results were reported by Elbakri (2009) who found that drinking water samples were polluted by coliform bacteria E. coli from Elhasahisa city. Also Salih (2013) found that water from Omdurman city was contaminated by the E. coli and coliform, Al Khiry (2016) reported that some water samples were contaminated by coliform, E. coli and faecal streptococcus bacteria in Khartoum city. Other researchers found high levels of coliform bacteria in water samples taken from Georg town in Guyana (Kurup et al., 2010). 
ISSN No:-2456-2165

\begin{tabular}{|c|c|c|c|c|c|c|c|c|c|c|c|c|c|}
\hline \multicolumn{4}{|c|}{ Autumn } & \multicolumn{4}{|c|}{ Summer } & \multicolumn{4}{|c|}{ Winter } & \multirow{2}{*}{\multicolumn{2}{|c|}{$\begin{array}{c}\text { Parameter } \\
\text { measure }\end{array}$}} \\
\hline $\begin{array}{l}\text { Detection of } \\
\text { salmonella }\end{array}$ & $\begin{array}{c}E \\
\text { coli }\end{array}$ & $\begin{array}{l}\text { Coliform } \\
\text { MPN) total } \\
\text { coliform }\end{array}$ & $\begin{array}{c}\text { Total } \\
\text { viable } \\
\text { count } \\
(\mathrm{cfu} / \mathrm{ml})\end{array}$ & $\begin{array}{l}\text { Detection of } \\
\text { salmonella }\end{array}$ & $\begin{array}{c}E \\
\text { coli }\end{array}$ & $\begin{array}{l}\text { Coliform } \\
\text { (MPN) total } \\
\text { coliform }\end{array}$ & $\begin{array}{c}\text { Total } \\
\text { viable } \\
\text { count } \\
(\mathrm{cfu} / \mathrm{ml})\end{array}$ & $\begin{array}{c}\text { Detection of } \\
\text { salmonella }\end{array}$ & $\begin{array}{c}E \\
\text { coli }\end{array}$ & $\begin{array}{l}\text { Coliform } \\
\text { (MPU) total } \\
\text { coliform }\end{array}$ & $\begin{array}{c}\text { Total } \\
\text { viable } \\
\text { count } \\
(\mathrm{cfu} / \mathrm{ml})\end{array}$ & & \\
\hline- & 1 & 9 & $10^{3} \leqslant 3.5$ & - & 0 & 0 & $10^{3} \leq 5.3$ & - & 0 & 5.33 & $10^{2} \leqq 4.5$ & 1 & Sample \\
\hline- & 0 & 10 & $10^{3} \div 8.0$ & - & 0 & 0 & $10^{3} \div 2.9$ & - & 0 & 0 & $10^{3} \div 3.4$ & 2 & number \\
\hline- & 0 & 0 & $10^{2} \leqslant 5.0$ & - & 0 & 0 & $10^{2} \leftleftarrows 45$ & - & 0 & 0 & $10^{2} \leftleftarrows 3.3$ & 3 & \\
\hline- & 5 & 13 & $10^{3} \div 4.9$ & - & 0 & 0 & $10^{3} \div 2.85$ & - & 0 & 0 & $10^{2} \lll 4,1$ & 4 & \\
\hline- & 2 & 7 & $10^{4} \leqslant 3.4$ & - & 0 & 0 & $10^{3} \div 3.3$ & - & 0 & 0 & $10^{3} \leq 5.0$ & 5 & \\
\hline- & 5 & 15 & $10^{4} \leqslant 5.1$ & + & 5 & 21 & $10^{3} \leqslant 7.7$ & + & 33 & 9 & $10^{3} \leqslant 5.16$ & 6 & \\
\hline- & 6 & 14 & $10^{3} \div 3.4$ & + & 3 & 21 & $10^{4} \leqslant 6.3$ & + & 2 & 12 & $10^{3} \div 1.73$ & 7 & \\
\hline- & 2 & 12 & $10^{4}: 7.3$ & - & 0 & 15 & $10^{3} \leqslant 4.6$ & - & 0 & 5.33 & $10^{3} \leqslant 6.1$ & 8 & \\
\hline- & 0 & 4 & $10^{3} \leqslant 3.6$ & - & 0 & 9 & $10^{3} \div 3.5$ & - & 0 & 0 & $10^{3} \div 3.2$ & 9 & \\
\hline - & 41 & 87 & $10^{5}: 8.6$ & + & 9 & 54 & $10^{4}: 7.4$ & + & 14.6 & 27.33 & $10^{4}: 7.3$ & 10 & \\
\hline
\end{tabular}

Table 2:- The microbial quality of water samples taken from Al Kamleen city, Gezira State During three seasons (winter, summer and autumn)

It is worth mentioning that when a comparison was made between the three seasons (winter, summer and autumn) the most contaminated samples were taken in autumn, this was so because in autumn a high turbidity was detected, this turbidity can protect the pathogenic microorganism from the effects of disinfectants and stimulate the growth of bacteria during water storage.

\section{CONCLUSION}

Results indicated that all physicochemical measured parameters fall below the acceptable level of the International Standards. Most of the samples were contaminated by coliform and E. coli bacteria. It is recommended to make more effort in effective management and maintenance in water treatment in order to minimize the health risk.

\section{REFERENCES}

[1]. Abdel Halim, H.A. (2010). Physicochemical properties of drinking water from selected sources in Khartoum locality. M.Sc. Thesis, University of Khartoum.

[2]. Al Khairy, Hanan, B.A. (2016). Evaluation of drinking water quality in Khartoum State. Ph.D. Thesis, Faculty of Education, Alzaiem Alazhari University.

[3]. Ali M.F.Y. (2008). Physical and chemical assessment of drinking water from different source in Khartoum State. M.Sc. Thesis, Faculty of Agriculture, University of Khartoum.

[4]. APHA, AWWA and WPCF (1998). Standard methods for examination of water and waste water, 20 Edition, American Public health Association, Washington, D.C.

[5]. Elbakri, H.K.H. (2009). Evaluation of drinking water quality from surface and ground resources in Gezira State. M.Sc. thesis, University of Khartoum.

[6]. Harrigan, W.F (1998). Laboratory methods in food microbiology, $3^{\text {rd }}$ Edition, Printed in Great Britain by WBC Book Manufactures Bridgned Mid-Glamorgan.
[7]. IEPA (2001). Ireland Environmental Protection Agency, Parameters of water quality: interpretation and standards, Environment Protection Agency, Johnstown, p. 133.

[8]. Khojaly, H.B.N. (2011). Some physical and chemical characteristics of drinking water from different sources and sites in Khartoum State. M.Sc. thesis, Faculty of Agriculture, University of Khartoum.

[9]. Kurup, Rajini, Persaud Roland, Coesar Joh and Rajallincent (2010). Micro-biological and physiochemical analysis of drinking water in Georgetown, Guyana, Nature and Science, 8(8): 261265.

[10]. Salih, I.M. (1998). Study on domestic water supply in Khartoum Province. M.Sc. Thesis, Institute of Environmental Studies, University of Khartoum, Sudan.

[11]. SSMO (2015). Sudanese Standards and Metrology Organization, drinking water guidelines bulletin, Sudan.

[12]. WHO (1993). Guidelines for drinking water quality, World Health Organization, Geneva, Vol. 1.

[13]. WHO (2004). Guidelines for drinking water quality, Third edition incorporating first addendum, Geneva.

[14]. WHO (2006). Guidelines for drinking water quality, Third edition incorporating first addendum, Vol. 1, Recommendations, Geneva.

[15]. WHO (2007). World Health Organization. Chemical safety of drinking water. Assessing priorities of risk management, Geneva, Switzerland. 